\title{
Conflicts in Donbass and the Kerch Strait as an Element of the Neo-Imperialist Expansion Strategy of the Russian Federation in the Post-Soviet Area
}

\author{
Marcin Orzechowski \\ Ph.D., Assistant Professor, University of Szczecin (Szczecin, Poland) \\ E-mail: orzechowski.martin@gmail.com \\ https://orcid.org/0000-0001-7272-6589
}

\begin{abstract}
The subject of the article is the analysis of the situation in the eastern part of Ukraine and Kerch Strait. The emergence of two quasi-state entities greatly contributed to the destabilization of the political and social space in Ukraine. The involvement of the Russian Federation in maintaining separatist tendencies in the Donbas is assessed as interference in the internal affairs of Ukraine. From today's perspective, there are some new questions about the future of relations between Russia and Ukraine. Some analysts believe that the Russians consistently implement the strategy of neo-imperial expansionism and activities in Donbas are the next step to reintegration of the post-Soviet area. An important role is also played the implementation of the policy implemented by the president and government of Ukraine. The author tries to answer the question whether Novorossiya is a "new quality" in Russian policy concerning the postSoviet area, or rather key element in the strategy of "collecting lands" and another "hot spot", next to Transnistria, Abkhazia and South Ossetia, in the post-Soviet space that would destabilize the situation in the region.
\end{abstract}

Keywords: international relations; Russian Federation; Ukraine; regional conflicts; hybrid war

Received: October 13, 2018; accepted: November 1, 2018

Ukrainian Policymaker, Volume 3, 2018: 43-50.

https://doi.org/10.29202/up/3/6

\section{Introduction}

In the nineties, the Russian Federation unequivocally declared the desire to act as an "arbitrator" and "stability guarantor" in the post-Soviet space. Such has always been the policy of the Russian Federation, which has tried to keep Ukraine in its sphere of influence. All actions leading to the cooperation of the Kiev authorities with the Western countries were unacceptable to Vladimir Putin because they jeopardized Russian national interest. The current military doctrine and security strategy of the Russian Federation determine Moscow's pursuit of total control in the region and its rebuilding the position of the sub-power. The domination over the so-called "near abroad" (post-Soviet states considered by the Federation

(C) Orzechowski, Marcin, 2018 
to belong to the Russian sphere of influence) constitutes an indispensable element of this policy [Szporluk, 2000: 439].

Ukraine as an independent state was often referred to as a mistake of history [Moshes, 1998: 3]. Vladimir Putin himself publicly questioned Ukraine's ability to function as a sovereign entity in international relations during the Russia-NATO meeting in Bucharest in 2008.

The Russians invariably attached great importance to geopolitics as a determinant of actions in the internal and foreign policy of imperialist Russia regardless of whether they were ruled by the tsars, the first secretaries or presidents. The Russian Federation's political strategy has been diverting gradually towards neo-imperialist expansionism since around 2004. These actions are of diverse intensity. The geostrategic factor plays a substantial role here. The countries that either have natural resources that can compete with Russian natural resources or whose governments have declared policies at least partly independent of the pressure exerted by the Russian authorities have become the priority ones to fall under control. As for Ukraine, the specific syndrome of "indissolubility of fraternal nations" enters, which got particularly forceful after the "revolution of dignity" and the escape of the former president Viktor Yanukovych [Orzechowski, 2017a: 131].

\section{Conditions and implementation of the neo-imperialist expansion strategy in Ukraine}

The first declarative threat that the south-eastern part of Ukraine might secede from the country appeared when Viktor Yushchenko had won the presidential election in 2005 [Orzechowski, 2017b: 277]. At that time, some political leaders of the Party of Regions announced in Donetsk that they would seek federalization of the state and would like to establish the South-Eastern Ukrainian Autonomous Republic. The announcements sounded scary but, at that time, they were a kind of the game calculated to blackmail political opponents from Our Ukraine and Yulia Tymoshenko's Batkivshchyna party as well as Western public opinion.

All-too-well-known reference to the Russian state as a guarantor of rights and defender of the Russian-speaking population abroad seems to be the key element. The word "neighborliness" is the term used all too often in this context. It seems that Russian interpretation of the notion is slightly similar to another term, namely, the "strategic partnership", i.e. that, in both cases, we deal with the situation in which the states, such as Ukraine, accept the necessity to remain in the Russian Federation's sphere of interest and try to adjust their policy to meet, more or less, the strategic assumptions of Russian policy [Orzechowski \& Wolińska, 2017: 94]. However, the arguments for the legitimacy of the use of armed forces to protect Russians living in the former Soviet republics raise considerable concern. In this case, Vladimir Putin and his political establishment invoke such conceptual categories as: national interest, truth and justice [Orzechowski, 2017 b: 283].

All these elements form a coherent picture of conceptual foundations for Russian domination in the post-Soviet area. The main element here is the need to restore the unity of the "Russian people" sometimes also referred to as the "Russian-speaking community" [Orzechowski, 2015: 76]. The effective implementation of this concept may be achieved through the attempt to integrate the post-Soviet area either as the close block of Eurasian Economic Union or, in an extreme case, by creating a state body covering at least part of 
this area. It is precisely on the basis of the discussed community of the "Russian world" that the priority political project named Eurasian Economic Union is implemented [Wiśniewska, 2016].

Such a community could be based on the bond that links Russia with Ukraine and other states formed after the collapse of the USSR; it is more and more often referred to as the "Russian world - Russkiy Mir" [Orzechowski, 2017 b: 283]. The community is most often understood as that of Russian-speaking people who identify themselves with the Orthodox religion and culture and who refer to common values regardless of the citizenship and the ethnic background. According to this interpretation, the Russian-Ukrainian-Belorussian community should become the core of this Russian World together with its basic area - the Russian-speaking population of post-Soviet countries [Brooke, 2014].

The doctrinal assumptions of this policy claimed that the post-Soviet countries should refrain from participating in bilateral or multilateral co-operation projects that could, in any way, violate the strategic interests of the Russian Federation. In particular, this concerned possible cooperation with the North Atlantic Alliance and, to a lesser extent, with the European Union as well.

Secondly, these states should decisively commit themselves to respecting the political and cultural rights of the Russian-speaking population that lives there (including of the individuals with Russian citizenship).

Thirdly, the project of the Eurasian Economic Union should be one of the proposals of close political and economic integration dictated by the Russian Federation so that its strategic priorities were implemented. The fact that when it comes to Crimea and eastern Ukraine the possibility of using military force was emphasized in such a decisive way is a certain novelty. The military intervention would take place when the Russian authorities would recognize that the rules of security of Russian citizens and Russian soldiers stationedabroad were violated, or if such persons or their representatives would turn to Russia with a request for assistance. That was how the ex-President Yanukovych's proposal to justify armed intervention in Ukraine was interpreted; in turn, the annexation of Crimea was presented as stemming from implementation of the "nations' rights to self-determination" [Orzechowski, 2015: 67]. However, there was a clear lack of efforts to preserve the legality of the actions and procedures in both cases. This leads to the conclusion that, in the situation where reliable legal and legal-international arguments cannot be applied, the Russian Federation authorities justify the undertaken actions with the unwritten rules of equity and justice or, if need be, the Russian legislation regarding the issue under discussion.

For Russia, to regain control over the post-Soviet area by establishing the zone of exclusive Russian influence there and to force the West to recognize the status quo still remains the primary aim of Russian political strategy. The Russian military offensive in eastern Ukraine was accompanied by the Kremlin's increasingly more explicit use of rhetoric referring to the concept of the so-called Novorossiya, which was present in the political language of some separatists and Russian nationalists. It is noteworthy that the Russian troops that entered the Ukrainian area of Novoazovsk on August 27, 2014 carried the "flag" of Novorossiya [Menkiszak et al., 2017].

The campaign for the "unification" of the so-called Donetsk and Lugansk People's Republics into the Novorossiya confederation conducted by the Ukrainian politician Oleg Tsaryov aided by Russia politically and through propaganda is an interesting example of the support. His initiative that Russian historians were to write a textbook on the "history of 
Novorossiya" was one of his most controversial ideas. It was highly approved and received the official support of Sergei Naryshkin, the president of the State Duma, and the Russian Academy of Sciences [Menkiszak, 2015].

In the Ukraine itself, there is clearly a growing reluctance of part of the society towards the Ukrainian government and the president due to the lack of a positive breakthrough in the Donbass case. President Petro Poroshenko managed to concentrate the majority of power in his hands but he used it to strengthen his own position and not to keep his election promises. The moods of society as well as of its political elite are, therefore, closely dependent on the situation around Donbass [Olszański, 2017].

Indeed, the question whether — in the current difficult economic situation - Ukraine stands a chance to arrive at an advantageous solution of the Donbass issue remains the key one to find the answer to. Theoretically, there is the option to undertake force actions against both "republics" [Orzechowski, 2017a: 138]. Nevertheless, the highest military command must bear in mind the fact that should Ukraine gain an advantage over the separatists the regular Russian military units are likely to join the fight again.

Another thing is that the most active social activists are raising more and more objections to the leading politicians and entrepreneurs' use of the war as a pretext for abandoning or slowing down reform efforts, especially the fight against corruption and the so-called "deoligarchisation" that would undoubtedly contribute to improving social moods.

The Russian vision of Novorossiya clearly refers to actions aimed at incorporating this area into the Russian Federation. During the presidency of Viktor Yanukovych, Russia could, in a peculiar way, use another element of propaganda pressure on the rapprochement between the two nations. The President of Ukraine repeatedly emphasized that he was a deeply religious person and expressed his support for the Ukrainian Orthodox Church of the Moscow Patriarchate. During the presidency of Dmitry Medvedev, the Russians carried out propaganda activities that were the "germ" of a real offensive aimed at instigating separatist sentiments in South-Eastern Ukraine [Kościński, 2017]. The Ukrainian press wrote about the concept of the so-called "unitary Russian space" supposedly developed in the milieu of the Russian president and implemented, inter alia, by the Russian Orthodox Church. When the "Malorussian governor" (as Viktor Yanukovych is called by the Ukrainian internet users) came to power, this seemed to be a perfect opportunity for Russia to strengthen and expand its influence in Ukraine. The concept of "two societies - one nation" became one of the most important tools to achieve this goal [Turchenko \& Turchenko, 2015: 137-138]. The next stage of activities began after the escape of Viktor Yanukovych.

Pro-Russian demonstrations were advantageous for the Russian Federation as they contributed to the increase of destabilization in Ukraine [Shynkarenko, 2014]. On the other hand, the Ukrainian oligarchs tried to use them as a "bargaining chip" in negotiations with the newly elected authorities. However, the situation was getting more and more exacerbated until finally the local oligarchs lost control over its development. As a result, two self-proclaimed republics came into being and, from that moment on, the actions to establish the legitimacy of their existence became one of their main goals. The referendum held on 11 May 2014, though declared illegal by the international community, was the first step; the central authorities election held on November 2 of the same year was the next one. Both votes failed to meet any democratic requirements [Piechal, 2016].

The main strategies goal of the Russian Federation in that period was the reconstruction of the Ukrainian government in such a way that would allow a split within the parliament; 
should this be the case, it could, in the long run, contribute to such state reforms that would sanction the granting of broad political and economic autonomy to the east and southern regions, i.e. federalization. In practice, this would mean that the Russian Federation could extend its influence over Ukraine and its internal and, especially, foreign policy. The so-called "political monitoring" of the emerging political and business establishment in Novorossiya was supposed to be an additional element of the impact. This would practically mean the ability to exert the influence on the leaders of both Republics. Russia could thus secure a direct impact on potential decision-making centers in both Donetsk and Lugansk.

The Russian Federation also undertook a diplomatic offensive directed at Western states to persuade both the United States and the European Union to require the Ukrainian authorities to recognize the Russian demands for broad autonomy of Donbass and the constitutional reform in Ukraine. The "Western diplomatic offensive" was primarily intended to convey a clear signal that Russia treats both the United States and the European Union as partners with which it should cooperate in solving the conflict in Donbass [Strzelecki, 2015]. On the one hand, this was undoubtedly the result of the increasingly severe impact of the sanctions imposed on the Russian Federation; on the other hand - it showed that although Russians implied they are not a party to this dispute, they repeatedly emphasized their role as the "hegemon and guardian" of the post-Soviet space and even invited "their Western partners" to resolve the existing dispute together [Orzechowski, 2015: 265].

The statements given by the president of the Federation Council Committee on foreign affairs of the Federation Council, Konstantin Kosachov was an element of the pressure exerted by Russia on Ukraine and Western countries. In one of them, posted on his blog, he stated, inter alia, that unless Donbass receives broad autonomy within Ukraine, the region may follow the "way of the Crimea" [Morello \& Lally, 2016]. Other representatives of the Russian establishment put forward further interesting postulates, for example, the legalization of the armed separatist structures as "people's militia" or the complete resignation of Ukraine from possible membership in the North Atlantic Alliance. It is not difficult to guess that both the Ukrainian President Petro Poroshenko and the then Prime Minister Arseniy Yatsenyuk expressed strong objections against the demands. Neither did the Ukrainian authorities intend to abandon their Western aspirations nor take on the burden of keeping the hostile Kremlincontrolled separatists [Orzechowski, 2017b: 295].

All these elements indicate that the conflict in Donbass bears the characteristic features of the phenomenon often referred to as the $21^{\text {st }}$ century war or the hybrid war. Thus understood, a war can also manifest itself as subversive intelligence operations (surveillance or control over the government's actions), sabotage, and hacker attacks on a country's IT infrastructure or the activities of partisan groups.

As for the conflict in Eastern Ukraine, it can be described as a hybrid war whose main purpose is: to extend and maintain jurisdiction and administrative control over a given area, to protect the borders which define the range of this jurisdiction, to enforce constitutional principles and legal norms on the people living in the area, to ensure public order and to manage the natural resources and economic policy [Popescu, 2015]. The phenomenon of a hybrid war seems to be an ideal strategic variant used to destabilize the situation in a country by another country, which, for various reasons, does not want to get involved in an open military conflict. The actions taken by Russia in the territory of Ukraine are aimed at subordinating this state to the Russian Federation, thus making any form of cooperation between Ukraine and Western European military and political structures impossible [Bachman 
\& Gunneriusson, 2014]. The Russian Federation purposefully and systematically implements its strategic assumptions aimed at the disintegration of the country located on the Dnieper by means of modern technologies, propaganda, destabilization of IT infrastructure as well as conventional military attacks. The conflict in the Kerch Strait is the next part of this strategy. In September 2003, the construction of a causeway was begun on the continental side to connect the island of Tuzla to the Taman Peninsula, and thus to Russia. Doing three shifts, the construction workers were able to build $150 \mathrm{~m}$ of the causeway a day. The problem began when the causeway reached a pontoon, belonging to the Ukrainian border troops, anchored between the peninsula and the island. The area of the Azov Sea and the Kerch Strait belongs to the internal waters of Ukraine and Russia, whereas the island of Tuzla itself belongs to Ukraine. The Russian side indicated that the sea state borders were not delineated accurately and claimed that Tuzla was not an island but an extension of the underwater sand bar stretching from the Taman Peninsula.

On 25 November 2018, the Ukrainian Navy reported that its three ships - "Berdiansk", "Nikopol" and "Yani Kapu" were taken over by the Russians in the Kerch Strait; earlier, the ships were to be fired at. Petro Poroshenko, the President of Ukraine, called on the parliament to support the National Security and Defense Council's decision to impose martial law on 26 November 2018. The Federal Security Service alleged that the Ukrainian party did not apply for a transfer and its boats were not included in the schedule of navigation through the Kerch Strait. The Ukrainians informed, however, that the notification of transfer plans was made earlier, in accordance with the international regulations, to ensure safe navigation. The Russian navy occupied the Kerch Strait completely when Moscow had built a bridge that connected the annexed Crimea with the territory of Russia. The FSB detained all Ukrainian fishing vessels for several months, treating the Azov Sea as the Russian internal sea. Pursuant to the decision of the National Security and Defense Council of 6 September 2018, the proposal of the Ministry of Foreign Affairs of Ukraine regarding the dissolution of the Treaty of Friendship, Cooperation and Partnership between Ukraine and the Russian Federation, signed on 31 May 1997, was approved by the president of Ukraine, Petro Poroshenko.

\section{Conclusions}

Summarizing the considerations undertaken in this article, it should be stated that, from the propaganda point of view, the project Malorossiya/Novorossiya as an element of reintegration of post-Soviet space is justified. The cost of this project, mainly economic, remains an open question. The need to create Novorossiya as another element in the reconstruction of the new "Putinist" Russia is one of the crucial elements of its neo-imperialist policy. The main reason for creating Donbass and Lugansk People's Republics was to destabilize the situation in Ukraine permanently and to put pressure on the authorities in Kiev in order to change the constitution and include the two political entities in the Ukrainian political system, autonomous and politically controlled by Russia. It would be an ideal option if, in addition to gaining autonomy for Donbass, Ukraine could become so destabilized that it would become a split state in the future. There would be an unquestionable chance to incorporate other areas into the Empire, and this is the style of action that was characteristic of Russia when it built its imperialist position. Novorossiya has two roles to play in Russian plans. It will either become a key element in the strategy of "collecting lands" and will strengthen the image of Vladimir Putin as the new Emperor of Great Russia, or it will otherwise become another "hot 
spot", next to Transnistria, Abkhazia and South Ossetia, in the post-Soviet space that would destabilize the situation in the region and let Russia meddle in the internal affairs of other states.

\section{[D] References}

Bachman, Sascha-Dominik, and Hakan Gunneriusson. Terrorism and Cyber Attacks as Hybrid Threats: Defining a Comprehensive Approach for Countering $21^{\text {st }}$ Century Threats to Global Peace and Security. The Journal on Terrorism and Security Analysis, Spring 2014，9 ${ }^{\text {th }}$ Edition, http://eprints.bournemouth.ac.uk/21206/1/Terrorism_and_Cyber_ Attacks.pdf

Brooke, James. Is 'Soviet Union light' the Future of Putin's Russia? 05.10.2012. http://www. voanews.com/content/soviet-union-light-future-putin-russia/1521341.html

Kościński, Piotr. Rosjanie i Ukraińcy — dwa społeczeństwa, jeden naród?, 18.06.2010. http:// www.rp.pl/artykul/496147-Rosjanie-i-Ukraincy---dwa-spoleczenstwa--jeden-narod-. html\#ap-1

Menkiszak, Marek. Strategia Rosji wobec kryzysu ukraińskiego, 05.03.2014. https://www.osw. waw.pl/pl/publikacje/analizy/2014-03-05/strategia-rosji-wobec-kryzysu-ukrainskiego

Menkiszak, Marek, Rafat Sadowski, and Piotr Żochowski. Rosyjska interwencja zbrojna we wschodniej Ukrainie, 03.09.2014. https:/www.osw.waw.pl/pl/publikacje/ analizy/2014-09-03/rosyjska-interwencja-zbrojna-we-wschodniej-ukrainie

Morello, Carol, and Kathy Lally. Crimea solidifies ties with Russia ahead of referendum on leasing Ukraine, Washington Post, 07.03.2014. https://www.washingtonpost.com/ world/europe/crimea-solidifies-ties-with-russia-ahead-of-referendum-on-leavingukraine/2014/03/07/daa96f90-a5eb-11e3-84d4-e59b1709222c_story.html

Olszański, Tadeusz A. Ukraińska polityka: układ sit po trzech latach wojny, 27.04.2017. https://www.osw.waw.pl/pl/publikacje/komentarze-osw/2017-04-27/ukrainskapolityka-uklad-sil-po-trzech-latach-wojny

Orzechowski, Marcin. Noworosja jako element dekonstrukcji państwowości Ukrainy I odbudowy mocarstwowej pozycji Rosji w regionie. Wschodni Rocznik Humanistyczny, Vol. XIV, Nr. 4, 2017: 129-142.

Orzechowski, Marcin. Noworosja jako element postzimnowojennego modelu integracji na obszarze poradzieckim, Ukraina. Czas przemian po rewolucji godności, [w:] A. Furier (red.), 2017: 274-304.

Orzechowski, Marcin. Od realnego pragmatyzmu do neoimperialistycznego ekspansjonizmu. Ewolucja strategii politycznej Federacji Rosyjskiej wobec Ukrainy, Szczecin, 2015.

Orzechowski, Marcin. Strategie polityczne Federacji Rosyjskiej wobec państw obszaru Europy Wschodniej w latach 1990-2005, Toruń, 2013.

Orzechowski, Marcin, and Paulina Wolińska. Turbulencje na obszarze poradzieckim na przykładzie konfliktu w Donbasie. Implikacje dla bezpieczeństwa europejskiego. Europa wobec problemów bezpieczeństwa w XXI w., A. Wojtaszak (red.), 2017: 89-116.

Piechal, Tomasz. Republiki wojenne w Donbasie rok po wybuchu konfliktu, 17.06.2015. https:// www.osw.waw.pl/pl/publikacje/komentarze-osw/2015-06-17/republiki-wojenne-wdonbasie-rok-po-wybuchu-konfliktu

Popescu, Nicu. Hybrid war: Neither new nor Russian, January 2015. https://www.iss.europa. $\mathrm{eu} / \mathrm{sites} /$ default/files/EUISSFiles/Alert_4_hybrid_warfare.pdf 
Shporluk, Roman. Russia, Ukraine and the breakup of the Soviet Union, Hoover Institution Press, 2000.

Shynkarenko, Oleg. Russia's hybrid war in Ukraine. Institute for War \& Peace Reporting, 17.06.2014. https://iwpr.net/global-voices/russias-hybrid-war-ukraine

Strzelecki, Jan. Rosyjska polityka ,kija i marchewki” w sprawie Ukrainy, 20.05.2015. http://www.osw.waw.pl/pl/publikacje/analizy/2015-05-20/rosyjska-polityka-kija-imarchewki-w-sprawie-ukrainy

Turchenko, Galyna and Fedir Turchenko. Project "Novorossia": 1764-2014. The jubilee on the blood, Zaporozhye, 2015. 